\title{
A window on the Stout Centre its stained glass and origins
}

A feature of the Stout Research Centre's seminar room is a group of three Victorian stained-glass windows, retrieved by the Centre's first and founding director, Jock Phillips from the burnt-out Stout family home. In recounting the circumstances surrounding this act of restoration he also gives an intriguing insight into the founding of the Stout Centre.

\section{JOCK PHILLIPS}

So, you ask about those beautiful leadlight windows in the Stout Centre. Are you sure you really want to know? The full story is rather longer than you might expect: and it is going to involve a good deal of autobiography on my part - and I have always believed that once you start to write autobiography, your days are numbered. But I must admit the story has a nice symbolism and tells quite a lot about the origins of the Stout Centre. You asked for it - so here goes.

The story begins in that cruel and cold winter of 1981. On Saturdays there were marches in the street; on Sundays as light relief I began taking photos of stained glass windows. With a friend and stained glass artist Chris Maclean I decided to put together a book about the subject. The windows facing on to the Terrace had first inspired this idea; and we had photographed quite a number of the marvellous leadlights on the remaining mansions there. There was one in particular just down below the university which we left alone. The house

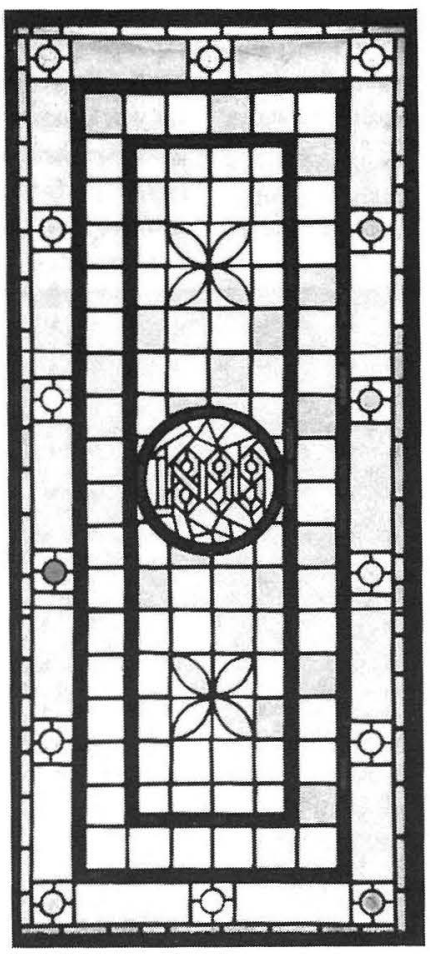

throwing a soft pink light into the dark space beneath. The windows seemed typical late Victorian works, a regular geometric pattern; and they were distinguished only by the very fine roundels down the side of each window. We photographed them; and it was only then that I noticed the initials RS in the middle of one. I slowly realised that this stood for Robert Stout and that we were standing in the home of a former Chief Justice, Prime Minister and founder of Victoria University of Wellington. In the other window were the initials of his wife and distinguished temperance advocate and suffragist Anna P. Stout.

At the time it was less the windows that had me excited than the possibilities of the building. Here was a large historic home a quarter of a mile from the university. It was also close to the Turnbull Library, then situated in the Freelance Building on the Terrace. My first thought was that we could use the old home for the History Department and get out of that awful tower, Rankine Brown. I soon dismissed that - it was too far from the staff common room to be acceptable. Then another idea dawned. Why not establish a research centre for New Zealand studies here? Like others of my generation I was gradually weaning myself away from the study of larger cultures and had begun to explore my own society. Surely Wellington was the place to set up something like this. The libraries and the archives were here; and people from other places in New Zealand and from overseas were starting to come to Wellington to do was always locked and deserted and the fan-light windows seemed thin and ordinary. Then one Sunday a friend who was looking at the property to buy it suggested we come and have a peer inside. It was an eery experience. The place had been a boarding house for some time; and was now deserted. It was cold and dark - there was no electricity - and many of the fittings on the doors and in the bathroom had been stolen. But above the landing of the stairs were three windows research. I thought of overseas models - the Humanities Research Centre at Canberra and more especially the Charles Warren Center for American History at Harvard University. I had often visited the Warren Center as a graduate student and had revelled in its calm scholarly atmosphere. An idea was born.

The following year an energetic Vice-chancellor, Ian Axford, arrived at Victoria. He announced immediately that he wished to raise the research profile of the 
university. I had the temerity to outline my vision of a New Zealand studies centre with him; and I found him full of enthusiasm. He encouraged me to pursue the idea; and by the time it had gelled sufficiently in mid 1983 to be presented to the Professorial Board, I discovered that the Vice-chancellor already had a building marked out for us. He had moved his own office down to Wai-te-ata Road. He wished to look out of his study and gaze at the fruits of his labour, a series of research institutes. He had already set aside one building in Wai-te-ata Road for the Institute of Policy Studies. Now he determined that the tiny art deco bugalow at No. 12 should be the New Zealand Studies centre. When he promised an architect-designed top floor with a seminar room and that splendid view of Wellington, I did not complain. Any thoughts of the Stoutmansion on the Terrace disappeared from my mind.

Three events brought the Stout windows and the New Zealand studies centre back together. First one day as we set out to look for financial support for the new centre, I met David Wylie in the library. He had just been appointed to a new trust, the John David Stout Trust, established from the estate of Robert Stout's grandson, John David, a distinguished scientist. The trust was dedicated to the support of New Zealand culture; and David Wylie suggested we apply for a fellowship for the new centre. We did so and they accepted the idea.

The second event was a dispute about the centre's name. When we presented the concept to the Professorial Board, the members of the Maori Studies Department expressed the view that a 'New Zealand Studies Centre' would appear to include study of the Maori people and culture. They believed that such study should occur within a Maori studies environment and they suggested that the centre should be called a 'pakeha studies centre'. In 1983 that was too radical a notion; and while we accepted that the centre should not try to take over studies of the Maori we did not wish to exclude such areas of interest. One idea which came forward was that the centre should take the name of the river on which Victoria stood, the Kumutoto. The Kumototo centre had a nice ring; and I was even more enthusiastic when I heard that the meaning of the word was 'flaming arseholes'. The 'flaming arseholes centre for New Zealand studies' - what more could one want? In the end of course such a suggestion was not acceptable; and so we settled on the name of the chief supporter of the centre, the Stout Trust. In the event it was highly appropriate. John David Stout's bequest funded the Fellowship which was the flagship of the centre; while Robert Stout, the grandfather, was not only Victoria's effective founder and first Chancellor; he was himself a distinguished intellectual whose collection of pamphlets in the library were a treasure of 19th century intellectual life. So it became the Stout Research Centre.

The third event was the burning of the Stout mansion on the Terrace. It was not burnt to the ground but the damage was sufficiently serious for the house to be demolished. I thought immediately of those windows. I

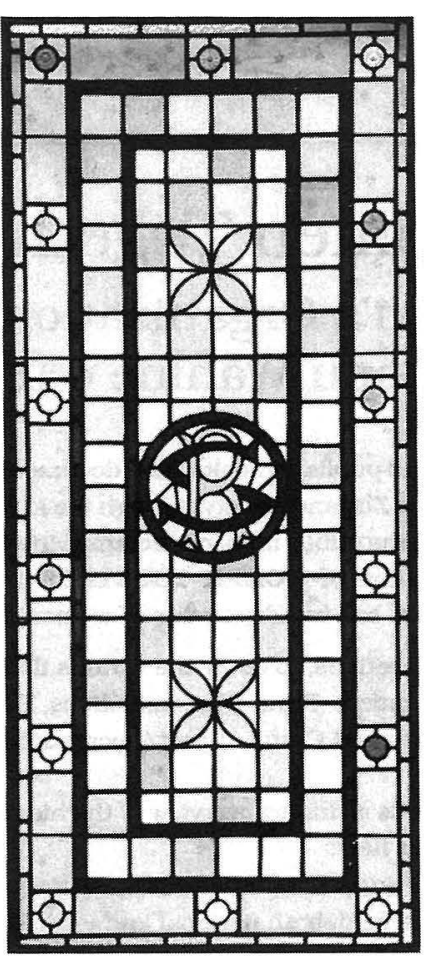
cannot now recall whether I went to the university and suggested they obtain the windows from the demolition firm; or whether the windows were offered to the university because of Robert Stout's connections with the place. What I do remember is going to have a look at them in the dungeons of the Hunter building. It was a sad sight. The wooden frames were badly charred; and the vast majority of the panes were cracked from the heat. Chris Maclean came along to look; and at first we thought it was a hopeless task trying to restore them. Then we noticed the small fanlights which had also been saved. They were less damaged; and Chris believed he could restore the windows by cannibalising the intact panes from the fanlights.

From then on things went smoothly. Jan Rotman, the university architect, designed a space on the south-east corner of the new seminar room for the windows; the Stout Trust provided some money for their restoration; Chris did a marvellous job restoring them; and his cousin, Peter Maclean, built some handsome Rimu frames. When we took up residence of 12 Wai-te-ata Road in mid 1984 the windows were back in a Stout House and were smiling benignly upon a centre for New Zealand studies.

So there you have it - a long tale, but one worth the telling. It is not always that coincidences are quite so happy. 